\title{
HAEMATOPOETIC EFFECT OF ETHYL ACETATE FRACTION OF HONEYCOMB IN RATS
}

\author{
${ }^{*}$ Babayi, H., ${ }^{1}$ Mustapha, A., ${ }^{2}$ Olayemi, K. I., ${ }^{3}$ Fadipe, A. L. \& ${ }^{4}$ Baba, E. \\ ${ }^{* 1}$ Department of Microbiology, Federal University of Technology Minna, Niger State, Nigeria \\ ${ }^{2}$ Department of Biological Sciences, Federal University of Technology Minna, Niger State, Nigeria \\ ${ }^{3}$ Department of Chemistry, Federal University of Technology Minna, Niger State, Nigeria \\ ${ }^{4}$ Clinic, National Institute for Pharmaceutical Research Development, Idu-Abuja, Nigeria \\ ${ }^{*}$ Corresponding Author Email: acadbabayi@yahoo.com Phone: +2348033700406
}

\begin{abstract}
Ethyl acetate fraction (Ec4) of honeycomb was evaluated for acute toxicity and haematopoietic effects in rats using standard methods. Oral $\mathrm{LD}_{50}$ of fraction Ec4 was $5000 \mathrm{mg} / \mathrm{kgbw}$. Oral administration of Ec4 (25 mg/kgbw, $50 \mathrm{mg} / \mathrm{kgbw}$ and $\left.100 \mathrm{mg} / \mathrm{kgbw}\right)$ for $28 \mathrm{days}$ did not cause any variation in neutophils, lymphocytes, monocytes, WBC, RBC PCV, MCHC, MCV and platelet counts of rats. Fraction Ec4 at $100 \mathrm{mg} / \mathrm{kgbw}$ evoked an insignificant $(\mathrm{P}>0.05)$ increase in the levels of basophil and significant $(\mathrm{P}<0.05)$ decrease in eosinophil counts in treated rats compared with the control. The results of this study revealed the potentials of honeycomb in stabilizing the immune system. Therefore, the fraction could be standardized and developed into affordable and acceptable phytomedicine for various ailments. But caution should be exercised on chronic exposure since it is capable of causing allergy in rats.
\end{abstract}

Keywords: Ethylacetate fraction, Haematology, Honeycomb, LD $D_{50}$, Rats

LICENSE: This work by Open Journals Nigeria is licensed and published under the Creative Commons Attribution License 4.0 International License, which permits unrestricted use, distribution, and reproduction in any medium, provided this article is duly cited.

COPYRIGHT: The Author(s) completely retain the copyright of this published article.

OPEN ACCESS: The Author(s) approves that this article remains permanently online in the open access (OA) mode.

QA: This Article is published in line with "COPE (Committee on Publication Ethics) and PIE (Publication Integrity \& Ethics)". 


\section{INTRODUCTION}

The use of natural products in treatment of various illnesses is increasing globally. It is widely accepted that the use of natural products and its derived principles will offer access to effective medical care for the treatment and management of diseases (Lawal et al., 2015a, Tsado et al., 2016). It is however, recommended that safety should be the overriding criterion in the selection of these natural products for health care needs (Shittu et al., 2015).

One of such natural products is honey comb. Honeycomb commonly called 'AfaraOyin' in Yoruba, 'Ogbugbo' in Igbo and 'Sa arZuma' in Hausa language, is a mass of hexagonal wax cells built by honey bees in their nests to contain their larvae and stores of honey and pollen (Graham, 1992). The healthiest honey is the one obtained directly from the combs and it is harvested for many uses. Honeycomb contains flavonoid, a useful compound which is present in all other bee products. Chewing honeycomb cleans the teeth, disinfect oral cavity, cleans gum and helps in removing plague (Molan, 1992). It has positive effects on airways (Cunha et al., 2007, Bogdanov, 2017). Regular chewing of honeycomb for 4-6hrs during allergy season will alleviate sneezing, runny nose and watery eyes (Ghapanchi, 2012). Honeycomb is therefore a great tool for treating cold (Mirzoeva, 1997). Marloive (2014) reported that bacteria cannot survive in bee product because of its potassium, high sugar content and low $\mathrm{pH}$. Thus, raw honey from comb can be used to treat scarring and many infections, as a facial moisturizer, a mask and body scrub. Bee products clean the blood vessels and aids digestion because of its antioxidant and anti-bacterial properties (Bogdanov, 2017, Effa, 2011).

Ghapanchi et al. (2011) reported that there are plethora of studies pointing to the potential roles of bee products in prevention and progression of tumor and cancer because of its carcinogen preventing and anti-tumor properties. One of the better-known health benefits of bee products (honey, honeycomb, propolis, venom and wax) is their ability to help treat sore throats (Basic, 2005). Despite the toxic attribute of natural products, more than $75 \%$ of the world population relies on natural products for their health care needs. However, despite widespread use, few scientific studies have been undertaken to ascertain the safety of many natural remedies (Bashir et al., 2015).

Therefore, information on honeycomb toxicity is useful in discovery novel drugs. The present investigation was designed to assess the effects of subchronic administration of ethylacetate fraction of honeycomb on rats by focusing on haematological indices.

\section{MATERIALS AND METHODS COLLECTION AND IDENTIFICATION OF MATERIALS}

Fresh honeycomb was collected from Apiary at Gidan Zuma Area, Suleja Local Government, Niger State, Nigeria in the month of June, 2015. The honey was first extracted from the comb prior to bioassay with electric honey extractor. The identification and authentication of the sample were done by senior Apiarist and an entomologist from the Entomology Unit, Department of Animal Biology, Federal University of Technology, Minna. Voucher specimen was preserved in the Department for future reference. 


\section{PREPARATION OF HONEYCOMB FOR EXTRACTION}

The honeycomb was air dried at room temperature for 3-4 weeks. The air-dried honeycomb was pulverized into powdery form using an electric blender.

\section{EXTRACTION AND FRACTIONATION OF HONEYCOMB}

Six hundred grams $(600 \mathrm{~g})$ of powdered honeycomb was refluxed with $3 \mathrm{~L}$ of $\mathrm{n}$-hexane for 6 hours to defat it. The resulting mixture was filtered and concentrated with a rotary evaporator at $45-50{ }^{\circ} \mathrm{C}$ to obtain an extract labeled as $\mathrm{n}$ hexane extract of honeycomb (coded $\mathrm{Hc}$ ). The marc was air-dried, repacked and re-extracted with 3L of ethylacetate for 6hours. The resulting mixture was filtered, concentrated and dried over a rotavapour. The residue was labelled as ethylacetate extract of honeycomb (coded Ec).

Crude ethylacetate extract of honeycomb (Ec) was further fractionated using Vacuum-Liquid Chromatography (VLC) as described by NIPRD (2004). Fifteen grams (15 g) of the gummy crude ethylacetate extract was dissolved in a small amount of ethylacetate and preabsorbed in silica gel (60-120 mesh) in order to make a smooth paste. The sample was made to dry, leaving the extract adsorbed to silica gel. The air-dried extract was pulverized to get a uniform powder. A sintered glass Buchner funnel was packed with $5.0 \mathrm{~g}$ of silica gel and sintered under vacuum to achieve a compacted uniform layer in the stationary phase.

Crude extract was packed into the column and eluted with varying proportions of increasing polarity of hexane (100:0), hexane- $\mathrm{CHCl}_{3}(1: 1), \mathrm{CH}_{3} \mathrm{Cl}_{3}$ - EtOAc (1:1), EtOAc - $\mathrm{MeOH}(1: 1)$. Eluents were collected in fractions of $200 \mathrm{~cm}^{3}$ each and identical fractions pooled using thin layer chromatography to obtain number of spots on the fractions. Four major fractions coded Ec1 - Ec4 were obtained. Ec4 displayed significant inhibitory effects on typhoid and paratyphoid bacilli (data not shown) and it was therefore subjected to acute and sub-acute toxicity testing.

\section{LABORATORY ANIMALS}

Adult healthy wistar rats Rattus novengicus of same weight group (120-200 g) were used in acute and sub-acute investigation. The animals were obtained from Animal House, Department of Basic and Applied Sciences, Zungeru Polytechnic, Minna, Niger State. They were housed in stainless steel cages bedded with dry clean wood shavings, maintained at a temperature of $\left(25 \pm 2{ }^{\circ} \mathrm{C}\right)$ and observed under $12 \mathrm{~h}$ light /dark cycle in well ventilated room two weeks before the commencement of the experiment. They were fed with standard animal feeds (Grower feeds and flour mills, Nigeria) and tap water adlibitum. The cages were cleaned and disinfected regularly. Soiled wood shavings were replaced often. The feed and water containers were washed daily. The animals were housed and cared for in accordance with good laboratory practice (GLP) regulations of WHO (1998). The principle of laboratory animal care (National Institute of Environment and Health services, NIHES, 1985) was also followed throughout the study.

\section{ACUTE ORAL TOXICITY OF ETHYLACETATE FRACTION OF HONEYCOMB}

The acute and sub-chronic toxicity studies of most active honey comb fraction (Ec4) were conducted as described by Aniagu et al. (2005). 
The rats were fasted for 12 hours and weighed before the administration of the fraction. The acute study was conducted to observe the range of toxicity so the proper dose level could be established. The study was conducted in two phases. In the first phase, nine rats were divided into 3 groups of 3 rats each. Group 1, 2 and 3 animals were administered orally with $10 \mathrm{mg} / \mathrm{kgbw}, 100 \mathrm{mg} / \mathrm{kgbw}$ and $1000 \mathrm{mg} / \mathrm{kgbw}$ for Ec4 respectively. In the second phase, the experiment was set up like the first phase of three groups with 1 rat per group. Group 1, 2 and 3 animals were administered with $1600 \mathrm{mg} / \mathrm{kgbw}, 2900 \mathrm{mg} / \mathrm{kgbw}$ and $5000 \mathrm{mg} / \mathrm{kgbw}$ of the fraction respectively. The weight of the rats was taken again one week after administration of the fraction. The volume of Ec4 to be administered according to the weight of the rat was calculated using the formula:

$$
\text { Volume }\left(\mathrm{cm}^{3}\right)=\frac{\text { weight of the animal }(\mathrm{g}) \times \text { Dose administered }(\mathrm{mg})}{\text { concentration }(\mathrm{mg} / \mathrm{mL})} \times \frac{100}{1}
$$

\section{SUB-CHRONIC STUDY}

Thirty rats (30) were selected and divided into six (6) groups of five rats each. Three groups were given $25 \mathrm{mg} / \mathrm{kgbw}$, $50 \mathrm{mg} / \mathrm{kgbw}$ and $100 \mathrm{mg} / \mathrm{kgbw}$ of the fraction orally for 28 days while the fourth group served as immune suppresant group which was administered with dexamethasone ( $3 \mathrm{mg} / \mathrm{kgbw})$. The fifth group served as immuno-stimulant group administered Jobelyn formula $(4.17 \mathrm{mg} / \mathrm{kgbw})$. The sixth group was control which was fed with water. The body weights of the rats were taken once before dosing commenced, once weekly during dosing and on the day of sacrifice.

At the end of the four weeks treatment, the animals were starved for 24 hours, but had access to water ad libitum. They were sacrificed under diethyl ether anaethesia. The blood for haematological analysis was collected through cardiac punture in EDTA bottles. The estimation of haematological parameters (Packed cell volume (PCV), haemoglobin count (HB), red blood cell count (RBC), platelets, white blood cell count (WBC), and differential count (monocytes, eosinophils, neutrophils and basophils) were determined using Darcie and Lewis (1991) method.

\section{STATISTICAL ANALYSIS}

Results were expressed as mean values \pm standard deviation (SEM). Within groups, comparisons were performed by the analysis of variance using ANOVA test. Significant differences between control and experimental groups were assessed by Duncan- test using SPSS version 19.0.

\section{RESULTS}

The acute oral toxicity profile of Ec4 is illustrated in Table 1. There was no death recorded in animals that received the fraction from $10 \mathrm{mg} / \mathrm{kgbw}-5000 \mathrm{mg} / \mathrm{kgbw}$. Furthermore, animals that received $10 \mathrm{mg} / \mathrm{kgbw}-1600 \mathrm{mg} / \mathrm{kgbw}$ were calmed and devoid of unusually reactions. The animals that received $2900 \mathrm{mg} / \mathrm{kgbw}-5000 \mathrm{mg} / \mathrm{kgbw}$ showed changes in general behavior and other physiological activities like restlessness, tarchycardia, hyperactivity, erythema and disorientation. Thus, no morbidity and mortality recorded in the study at all tested doses. From the above toxicity studies, $\mathrm{LD}_{50}$ of Ec4 was estimated to be greater than $5000 \mathrm{mg} / \mathrm{kgbw}$ in rats. 
Table 1: Acute Oral Toxicity Profile of Fraction $E_{C} 4$ of Ethyl Acetate Extract of Honeycomb

\begin{tabular}{lcl}
\hline Dose (mg/kgbw) & Mortality & Observations/ Toxicity sign \\
\hline 10 & $0 / 3$ & Animals showed no apparent change in appearance and activity. \\
100 & $0 / 3$ & Animals were calmed and devoid of unusual reactions to mild physical stimuli. \\
1000 & $0 / 3$ & Animals were calmed and devoid of unusual reactions to mild physical stimuli. \\
1600 & $0 / 3$ & Animals were calmed and devoid of unusual reactions to mild physical stimuli. \\
2900 & $0 / 3$ & Lacrimation observed among some of the animals. Others exhibited hyperactivity, restlessness and slight \\
& & erythema. \\
5000 & $0 / 3$ & Animals had intense erythema, tarchycardia and disorientation. \\
\hline $\mathrm{Mg} / \mathrm{kgbw}:$ Milligram per kilogram body weight &
\end{tabular}

Table 2 shows change in differential leucocyte of rats following chronic administration of Ec4 $(25 \mathrm{mg} / \mathrm{kgbw}, 50$ $\mathrm{mg} / \mathrm{kgbw}$ and $100 \mathrm{mg} / \mathrm{kgbw}$ ). There was no significant ( $\mathrm{P}>0.05)$ difference in neutrophil, lymphocytes and monocyte counts of the rats administered the treatment including dexamethazone and Jobelyn groups when compared to the control. However, there was significant $(\mathrm{P}<0.05)$ reduction in eosinophil counts of the rats that received $100 \mathrm{mg} / \mathrm{kgbw}$ of Ec4. Rats treated with $50 \mathrm{mg} / \mathrm{kgbw}, 100 \mathrm{mg} / \mathrm{kgbw}$ and dexamethasone showed insignificant $(\mathrm{P}>0.05)$ difference in basophil counts when compared with the control while those that received Jobelyn had significant $(\mathrm{P}<0.05)$ raise in basophil count.

Table 2: Differential counts of rats administered fraction $E_{c} 4$ of ethyl acetate extract of Honeycomb

\begin{tabular}{|c|c|c|c|c|c|c|}
\hline \multirow[b]{2}{*}{$\begin{array}{c}\text { Differential } \\
\text { leukocyte }\end{array}$} & \multicolumn{6}{|c|}{ Treatments (mg/kgbw) } \\
\hline & Control & 25 & 50 & 100 & DEX(3) & JOB(4.17) \\
\hline Neutrophil & $48.40 \pm 2.9^{\mathrm{a}}$ & $46.20 \pm 1.6^{\mathrm{a}}$ & $46.20 \pm 1.82^{\mathrm{a}}$ & $47.40 \pm 1.9^{\mathrm{a}}$ & $50.40 \pm 3.65^{\mathrm{a}}$ & $46.60 \pm 4.29^{a}$ \\
\hline Lymphocyte & $47.40 \pm 0.67^{\mathrm{a}}$ & $47.00 \pm 0.89^{\mathrm{a}}$ & $46.40 \pm 1.32^{\mathrm{a}}$ & $47.40 \pm 1.80^{\mathrm{a}}$ & $42.80 \pm 1.20^{\mathrm{a}}$ & $45.40 \pm 4.37^{\mathrm{a}}$ \\
\hline Monocyte & $4.80 \pm 1.31^{\mathrm{a}}$ & $4.00 \pm 0.54^{\mathrm{a}}$ & $4.80 \pm 0.91^{\mathrm{a}}$ & $4.20 \pm 0.20^{\mathrm{a}}$ & $4.20 \pm 0.91^{\mathrm{a}}$ & $4.60 \pm 0.97^{\mathrm{a}}$ \\
\hline Eosinophil * & $2.60 \pm 0.74^{b}$ & $2.80 \pm 0.37^{b}$ & $2.40 \pm 0.24^{\mathrm{b}}$ & $1.80 \pm 0.37^{\mathrm{a}}$ & $2.40 \pm 0.60^{\mathrm{b}}$ & $2.80 \pm 0.80^{\mathrm{b}}$ \\
\hline Basophils * & $0.00 \pm 0.00^{\mathrm{a}}$ & $0.00 \pm 0.00^{\mathrm{a}}$ & $0.20 \pm 0.00^{\mathrm{ab}}$ & $0.20 \pm 0.00^{\mathrm{ab}}$ & $0.20 \pm 0.00^{\mathrm{ab}}$ & $0.60 \pm 0.00^{\mathrm{b}}$ \\
\hline $\begin{array}{l}\text { Values } \\
*: \text { Valı } \\
\text { JOB: J } \\
\text { DEX: } \\
\mathrm{Mg} / \mathrm{kg}\end{array}$ & $\begin{array}{l}\text { e means } \pm \text { S.E.N } \\
\text { along the same } \\
\text { elyn } \\
\text { xamethosone } \\
\text { : Milligram per }\end{array}$ & $\begin{array}{l}\text { h different supe } \\
\text { a body weight }\end{array}$ & are significantly & fferent $(\mathrm{p}<0.05)$ & n each other. & \\
\hline
\end{tabular}

Table 3 presents change in haematological indices in rats following chronic treatment with Ec4 (25 mg/kgbw, 50 $\mathrm{mg} / \mathrm{kgbw}$ and $100 \mathrm{mg} / \mathrm{kgbw})$. The results showed that there was no significant $(\mathrm{P}>0.05)$ variation in $\mathrm{PCV}$, platelet, $\mathrm{MCHC}, \mathrm{MCH}$ and MCV counts following administration of the treatments. However, there was significant upsurge in white blood cells (WBC) in the group that received dexamethasone while the group that received jobelyn had their RBC significantly $(\mathrm{P}<0.05)$ increased. Groups administered $25 \mathrm{mg} / \mathrm{kgbw}, 50 \mathrm{mg} / \mathrm{kgbw}, 100 \mathrm{mg} / \mathrm{kgbw}$ and dexamethasone displayed decreased haemoglobin (HB) level when compared with the control group. The group that received Jobelyn compared well with the control in HB level.

\section{DISCUSSION}

The results of acute oral toxicity of fraction Ec4 of ethylacetate extract $(\mathrm{Ec})$ of honey comb suggests that the fraction could be relatively safe on acute exposure even at a high dose. The oral $\mathrm{LD}_{50}$ was greater than $5000 \mathrm{mg} / \mathrm{kgbw}$ and is 
similar to the value obtained by Lawal et al. (2015b) on Nigerian bee propolis and other animal products like haemolymph of Achachatina maginata (Lawal et al., 2015c).

Absence of change in movement or occurrence of piloerection or diarrhoea or any abnormal behavior in animals exposed to dose range of $10 \mathrm{mg} / \mathrm{kgbw}-1600 \mathrm{mg} / \mathrm{kgbw}$ suggest that this dose range can be considered safe for therapeutic purpose. Evaluation of haematological indices provides useful information on the adverse effect of foreign component in the blood and also explains blood - related functions of chemical compounds (Berinyuy et al., 2015). Differential leukocytes counts are indices of the white blood cells and principally the haematological indication of immunity. The results obtained in this study revealed that there was no significant $(\mathrm{P}>0.05)$ variance in the differential leukocytes count (monocytes, neutrophils and lymphocytes) when compared with the control. This suggests that the fraction did not induce toxic effects that may elicit leukopoesis in rats.

The significant decrease in levels of eosinophil and elevation in basophil count in treated rats with 100 $\mathrm{mg} / \mathrm{kgbw}$ and Jobelyn formula suggest allergic reactions and parasitic infections in the blood. This observation is similar to the findings of Berinyuy et al. (2015) who reported high levels of basophil and eosinophil counts in rats after chronic administration of Cassia occidentalis.

Red blood cells and factors relating to it are major indices for evaluating circulatory erythrocytes and are significant in the diagnosis of anaemia and also serve as useful indices of the bone marrow capacity to produce RBC in mammals (Peter et al., 2011, Ozkan et al., 2012). The non- expressive ( $>>0.05)$ effects of the fraction on the PCV, $\mathrm{RBC}, \mathrm{HB}, \mathrm{MCHC}, \mathrm{MCH}, \mathrm{MCV}$ counts throughout the experimental period is an indication that there was no destruction of matured RBCs and no change in the rate of production of RBCs (erythropoiesis). It further showed that the fraction does not have the potential to stimulate erythropoietin release in the kidney, which is the humoral regulator of RBC production (Mishra and Tandon, 2012). However, the significant decline in HB in rats that received the treatment ( $25 \mathrm{mg} / \mathrm{kgbw}, 50 \mathrm{mg} / \mathrm{kgbw}$ and $100 \mathrm{mg} / \mathrm{kgbw})$ with the drug, dexamethasone is an indication of anaemic condition. Thus, a rise in RBC level in the group exposed to the jobelyn formula also may be a sign of erythropoiesis, probably, the drug contains some erythropoietin- inhibitory components which reduced the rate of erythropoietin release with consequent upsurge in RBC productions. The elevation could be attributed to the destruction of matured RBCs by components of the drug.

The major function of the white blood cells and its differentials are to fight infections, defend the body by phagocytosis against invasion by foreign organisms and to produce or at least transport and distribute antibodies in immune response (Lawal et al., 2015a). The non-significant effect of the fractions on the WBC and factors relating to it is an indication that the fraction has no leucopoetic and immune-modulatory tendency when administered to the rats. However, the significant increase in WBC following the administration of dexamethasone may be as a result of stress induced by the drug metabolism in the system of the animals which augmented the production of more WBC to overcome the stress (Bashir et al., 2015).

\section{CONCLUSION}

The results obtained in this study suggest that ethylacetate fraction of honeycomb is not toxic to the kidney on chronic exposure and exhibit the potential to stabilize the immune system. 


\section{ACKNOWLEDGMENT}

The authors are grateful to the Department of Microbiology Federal University of Technology, Minna for providing enabling environment for the study.

\section{REFERENCES}

Aniagu, S.O., Nwinyl, F. C., Akumka, G.A., Dzarma, S., Izebe, K.S. and Gamaniel, K. (2005). Toxicology studies in Rats fed nature cure bitters. African Journal of Biotechnology 4(1): 72-70.

Bashir L, Shittu O.K., Busari M.B., Sani S. \& Aisha M.I. (2015) Safety Evaluation of Giant African land Snails (Archachatina marginata) Haemolymph on Hematological and Biochemical Parameters of Albino Rats. Journal Advance Medical Pharmarceutical Scociety, 3(3), 122-130.

Berinyuy, E.B., Lawal, B., Olalekan, A.A., Olalekan, A.A, Yusuf, A.A., Sakpe, S. \& Ossai, P.C. (2015). Hematological Status and Organs/Body-weight Parameters in Wister Rats during Chronic Administration of Cassia occidentalis. International Blood Research \& Reviews, 4(3), 1-7.

Bogdanov, S. (2017). Functional and Biological Properties of the Bee Products. Bee Product Science 1-40. Retrieved on $10^{\text {th }}$ May, 2018 from www.bee-hexagon.net

Basic, O. (2005). Salmonella Typhi.American Journal of Infectious Diseases and Microbiology, 1(1), 84-85.

Cunha, I., Neupath, T., Caeiro, S., Costa, M. H. \&Guilhermino, L. (2007). Toxicity ranking of estuarine sediments based on Sparusaurata biomarkers. Environment Toxicology Chemistry ,26, 444-453.

Dacie, J. \& Lewis, S. (1991). Practical Haematology, $7^{\text {th }}$ Ed. Churchill Livingston. Edingburgh.

Effa, E. E., Lassi, Z. S., Critchley, J. A., Garner, P., Sinclair, D., Olliaro, P. L. \&Bhutta, Z. A. (2011). ed. "Fluoroquinolones for treating typhoid and paratyphoid fever (enteric fever) (ed.), Cochrane Database Sysemt Review (10), CD004530.

Ghapanchi, J., Bazazargani, A., Daghigh, A. M., Balady, F. S. \& Dad, A. S. (2010). In vitro Assessment of antiStreptococcus mutanspotential of honey.Iranian Red Crescent Medical Journal. 12(1), 61-64.

Ghapanchi, J., Moattari, A., Andisheh, T. A., Talatof, Z., Shahidi, S. P. \&Ebrahimi, H. (2012). The In Vitro Anti-Viral Activity of Honey on Type 1 Herpes Simplex Virus.Australian Journal of Basic and Applied Sciences, 5(12), 849-852.

Graham, J. (1992). The Hive and the Honey Bee. Hamilton/IL: Dadant\& Sons

Lawal, B., Shittu, O.K., Abubakar, A.N., Umar, M.B., Ibrahim, A.M. \& Haruna, G.M. (2015a). Biochemical Evaluation in Wister Rats (Rattus novergicus) Following Chronic Exposure of Methanol leaf Extract of Telfairia occcidentalis. Journal Pharmaceutical Biomedicine Science, 05(09), 740-744.

Lawal, B., Shittu, O.K., Abubakar, A.N., Haruna, G.M., Sani, S. \& Ossai, P.C. (2015b). Haematopoetic Effect of Methanol Extract of Nigerian Honey Bee (Apis mellifera) Propolis in Mice. Journal of Coastal Life Medicine, $3(8), 648-651$ 
Lawal, B., Shittu, O. K., Ossai, P. C., Abubakar, A. N. \& Ibrahim, A. M. (2015c). Antioxidant Activities of Giant African Snail (Achachatina maginata) Haemolymph against $\mathrm{CCl}_{4}$ - Induced Hepatotoxicity in Albino Rats. British Journal Pharmarceutical Research, 6(3): 141-154

Mirzoeva, O. K., Grisjanin, R. N. \& Calder, P. C. (1997). Antimicrobial action of propolis and some of its components: the effects on growth, membrane potential and motility of bacteria. Microbiology Research, 152(1), 239246.

Mishra, M. \& Tandon, V. L. (2012). Hematological effects of aqueous extract of Ornamental plants in male Swiss albino mice. Vetenary World, 5(1), 19-23.

Molan, P. C. (1992). The antibacterial properties of honey. BeeWorld, 73(1), 59-76.

National Institute of Environmental Health Sciences - NIEHS (1985). "Respect for life".

National institute for pharmaceutical research and development, NIPRD (2004). Extraction of of medicinal plants.Idu, Abuja, Nigeria

Ozkan, C., Kaya, A. \& Akgul, Y. (2012). Normal values of haematological and some biochemical parameters in serum and urine of New Zealand White rabbits. World Rabbit Science, (20), 253-259.

Peters, S. O., Gunn, H. H., Imumorin, I. G., Agaviezor, B. O. \&Ikeobi, C. O. N. (2011). Haematological studies on frizzle and naked neck genotypes of Nigerian native chickens. Tropical Animal Health Production, 43, 631638. prodent. New England Journal of Medicine, 356(1), 21-28.

Shittu, O. K., Lawa, I. B., Abubakar, N. A., Berinyuy, B. E., Busari, M. B. \& Ibrahim, A. O. (2015). Toxicological Implications of Methanol Extract from Nigerian Bee Propolison Some Selected Rat Tissues.Journal of Pharmarcy Biomedicine Science, 5(7), 524-531.

Shittu, O. K., Lawal,B., Uchenna, B. A. B., Haruna,G. M., Abubakar,A. N. \& Berinyuy, E. B. (2015a). Alteration in Biochemical Indices Following Chronic Administration of Methanolic Extract of Nigeria Bee Propolis in Wistar Rats.Asian Pacific Journal of Tropical Disease, 5(8), 654-657.

Tsado, N. A., Lawal, B., Ossa, P.C., Jagaba, A., Kontagora, G.N., Gboke, J.A., Umar, A. M. \& Oladunjoye, J. O. (2016). Antioxidants and Antimicrobial Activities of Methanol Extract of Newbouldialaevisand Cratevaadansonii.Journal of Pharmacy and Allied Health Sciences, 33(2), 11.

WHO (1998). Basic Principles of Good Laboratory Practice. Retrieved on $12^{\text {th }}$ May $12^{\text {th }} 2018$ from http://www.who.int/tdr/publications. 